UDC 622.013

A. O. Kozhevnykov ${ }^{1}$, Dr. Sc. (Tech.), Prof., orcid.org/0000-0002-2708-8917,

A. Yu. Dreus ${ }^{2}$, Cand. Sc. (Tech.), Assoc. Prof., orcid.org/0000-0003-0598-9287,

Baochang Liu ${ }^{3}$, Cand. Sc. (Tech.), Prof., A. K. Sudakov ${ }^{1}$, Dr. Sc. (Tech.), Assoc. Prof., orcid.org/0000-0003-2881-2855
DOI: $10.29202 /$ nvngu/2018-1/14

1 - National Mining University, Dnipro, Ukraine, e-mail: aak2@ua.fm

2 - Oles Honchar Dnipro National University, Dnipro, Ukraine, e-mail:dreus@mmf.dnulive.dp.ua

3 - College of Construction Engineering, Jilin University, Chanchun, China, e-mail: liubc@jlu.edu.cn

\title{
DRILLING FLUID CIRCULATION RATE INFLUENCE ON THE CONTACT TEMPERATURE DURING BOREHOLE DRILLING
}

А. О. Кожевников ${ }^{1}$, д-р техн. наук, проф., orcid.org/0000-0002-2708-8917, А. Ю. Дреус ${ }^{2}$, канд. техн. наук, доц., orcid.org/0000-0003-0598-9287, Баочанг Лю ${ }^{3}$, канд. техн. наук, проф., А. К. Судаков ${ }^{1}$, д-р техн. наук, доц., orcid.org/0000-0003-2881-2855
1 - Державний вищий навчальний заклад „Національний гірничий університет“, м. Дніпро, Україна, e-mail: aak2@ ua.fm

2 - Дніпровський національний університет імені Олеся Гончара, м. Дніпро, Україна, e-mail: dreus@mmf.dnulive.dp.ua 3 - Будівельний коледж Цзілінського університету, м. Чанчунь, Китай, e-mail: liubc@jlu.edu.cn

\section{ВПЛИВ ВИТРАТИ ПРОМИВАЛЬНОЇ РІДИНИ НА КОНТАКТНУ ТЕМПЕРАТУРУ ПРИ БУРІННІ СВЕРДЛОВИН}

Purpose. To establish the influence of drilling fluid circulation rate onto the contact temperature during the rotation drilling using an impregnated diamond drill bit; to verify the mathematical model of the diamond drill bit heating process in the course of boreholes drilling.

Methodology. Bench experiments and theoretical analysis using methods of mathematical modeling.

Findings. In the course of the bench experiments the data of influence of the drilling fluid circulation rate on the contact temperature during drilling of granite rock with a $59-\mathrm{mm}$ diameter drill bit were obtained. A relevant mathematical model of the drill bit heating under the variable rate of drilling fluid was represented on the basis of a system of the heat transfer differential equations. A comparative analysis of experimental and predicted data was carried out, and its findings positively confirm the reliability of the mathematical modeling of heat transfer processes in the downhole during bore-hole drilling.

Originality. The methodology of experimental measuring of the contact temperature during the bench experiment borehole drilling using resistance sensors was proposed herein. New experimental data was obtained which allowed establishing a correlation between the contact temperature and the rate of drilling fluid in the downhole area. The proposed mathematical model of the process is found to be adequate; it allows predicting the temperature mode on the working face of borehole in the course of drilling. The findings of the research make it possible to substantiate the effect of the diamond core drilling performance gaining due to transition from the fixed time operation parameters to the variable ones.

Practical value. The regularities of action of the drilling fluid circulation rate on the contact temperature of the "tool - working face" system in the course of borehole drilling were established. The performed research confirmed the possibility of managing the thermal mode of drilling by variation of the drilling fluid circulation rate. The diamond core drilling performance gains, therefore, are possible to achieve by way of increasing the thermal stimulation of the mining rock. The developed mathematical model allows forecasting the contact temperature in the course of borehole drilling for various values of the drilling fluid circulation rates. Using of this model makes it possible to define the permissible diminishing of the drilling fluid circulation rate in order to prevent any abnormal thermophysical wear of the drill bit.

Keywords: drilling, thermal mode, mathematical model, drill bits heating

Introduction. In recent years, there has been a trend towards a constant increase in the consumption of fuel and energy resources [1], and in this connection, there is a growing interest in studying geotechnological methods of extracting minerals by drilling wells. Using of the heat energy of friction generated in the down-hole area seems to be one of the reserves to enhance the perfor-

(C) Kozhevnykov A. O., Dreus A. Yu., Baochang Liu, Sudakov A. K., 2018 mance of diamond core drilling process. It is well known that increasing of the mining rock temperature results in a growing number of micro-fractures [2], decreasing its tensile and compressions strengths [3], and decreasing the velocity of the waves in the mining rock, and others. At that, the mining rock prefracture takes place during its thermal stimulation, which stipulates for increasing of the rock decomposition process efficiency in the course of further mechanical stimulation thereof. The analysis 
of thermodynamic effects in the course of mining rocks disintegration is carried out in [4].

Using the heating energy for mining rock decomposition is the basis of the innovative technologies of mining rocks disintegration such as jet drilling [5] thermal spallation drilling [6] or plasma drilling [7]. However, the above mentioned technologies use specific drilling equipment and devices.

It is quite possible, however, to effectively use the heat stimulation of the downhole areas in the course of traditional rotary drilling technologies. It is stipulated in work [8] that increasing the contact temperature in the downhole area allows creating certain conditions for mining rock weakening in the course of diamond core drilling. The friction heat, generated at the working face during the rotary drilling process, is the source of thermal energy. This approach makes it possible to enhance the efficiency of mining rock decomposition without a need to significantly amend the existing diamond bit rotary core drilling technology. An increase in the contact temperature can be achieved by switching the borehole flushing process to a non-typical mode of operation.

On the other hand, high contact temperatures may impose certain negative effect on the efficiency of the drilling tools. Therefore, nowadays, technologies of strengthening the surfaces of the drill tool for the effective operation in high temperatures [9] are increasingly being used, which slightly increases the permissible temperatures in the contact area of the drilling tools surfaces with the well. But for a modern drilling tool during the design of the drilling process, it is necessary to provide such modes of speed of circulation of the drilling fluid so that the temperature in the contact area with the well does not exceed the critical level of $600{ }^{\circ} \mathrm{C}$. To settle this challenge, it is necessary to examine the thermal condition of the "tool - working face" system in the course of the borehole drilling.

Analysis of the recent research and publications. Notwithstanding the fact that thermophysical processes in the downhole area during the borehole drilling have been a subject of numerous research works, until today there is no "universal" methodology which allows determining the contact temperature of the working face of borehole during diamond core rotary drilling [10].

Work [11] stipulates that drilling with pulse mode of drilling fluid circulation rate does not only result in the increase in the contact temperature, but also enhances the drilling velocity. The thermal factor plays a particular role during the drilling processes with air or gas flushing or foams flushing. The relation between the thermal factor and power consumption rates when drilling frozen rocks with air flushing was the subject of research in work [12]. Methods of mining rocks decomposition using the friction heat and gas flushing were considered in work [13]. The issues of heat exchange between the drilling fluid and tools, drilling fluid and mining rock in the course of geothermal bores drilling were discussed in work [14] where the mathematical model of the heat transfer in the surrounding mining rocks around the borehole was proposed.

In the course of the mathematical modeling of heat transfer processes in the drilling tools and the mining rock, it is essential to calculate the thermal balance on the contact line of drilling tools with the rock, taking into account the heat generated by the friction. The processes of friction heat generation on the contact line of the two solid bodies, and distribution of the resulting heat flows, were defined in work [15]. Work [16] dealt with research of the influence of the convection cooling on distribution of the generated friction heat. The gained results are the evidence that it is possible to control the thermal balance in the downhole area by way of changing the rate of convective cooling of the contacting bodies.

The matter of enhancing the efficiency of diamond core drilling by using the heat factor calls for researching of thermophysical processes in the downhole area in order to establish the influence of the drilling fluid circulation rate to the contact temperature of drilling [17]. At the moment, there are very few research works dedicated to this issue, while the achieved results represent only particular instances which, therefore, require an expand of the existing database of the experimental research findings.

On the other hand, it is necessary to have a calculation apparatus in place, which would allow forecasting the thermal mode of the drilling tools in order to prevent their overheating. Verification of the relevancy of the outcomes of mathematical modeling of thermophysical processes in the downhole area also requires related experimental data.

The objective of the article is to establish the influence of drilling fluid circulation rate on the contact temperature during the rotation drilling using an impregnated diamond drill bit and to verify the mathematical model of the diamond bit heating process in the course of boreholes drilling.

Experimental research. Bench experimental research studies were carried out in order to determine the contact temperatures during the process of diamond core drilling. This work was carried out in Jilin University (Chanchun city, China).

The goal of the bench experimental research was to determine the action of the drilling fluid circulation rate to the value of the contact temperature of the "drilling tool - working face" system. The mode of flushing was fixed for each particular experiment; however, the circulation rate of the drilling fluid was varied during each particular set of experiment. The outcomes of such research allowed evaluating the relation between the thermal condition of the downhole area and the rate of the drilling fluid during the process of drilling.

Resistance sensors of Pt100 type were used to determine the temperatures on the contact line of the drilling tools with the mining rock in the course of diamond bit drilling. The principle of temperature value reading by the sensors of Pt100 type is based on increase in the electrical resistance of the sensor during increasing of the temperature. The measuring resistor is powered by the direct current. The temperature gap on the sensor is changed depending on the temperature.

Pt100 sensors contain 3 cable wires. Heat absorption element (a diode) is located in the $4 \times 50 \mathrm{~mm}$ protective sleeve. Each sensor has a connection cable with protection screen. The sensors accuracy is in conformity with Class B (Table 1). According to their specifications, the maximal measuring temperature of the sensors is $500{ }^{\circ} \mathrm{C}$. 
Table 1

Accuracy of reading of Pt100 resistance sensors

\begin{tabular}{|c|c|c|c|}
\hline Range & \multicolumn{3}{|c|}{ Maximum deviation } \\
\hline${ }^{\circ} \mathrm{C}$ & $\begin{array}{c}\text { Class B, } \\
\mathrm{K}\end{array}$ & $\begin{array}{c}\text { DIN Class } \\
\mathrm{A}, \mathrm{K}\end{array}$ & $\begin{array}{c}1 / 5 \text { DIN } \\
\text { Class B, K }\end{array}$ \\
\hline At -200 & \pm 1.3 & - & - \\
\hline At -100 & \pm 0.8 & - & - \\
\hline At -50 & - & \pm 0.25 & - \\
\hline At 0 & \pm 0.3 & - & - \\
\hline At +100 & \pm 0.8 & \pm 0.15 & \pm 0.06 \\
\hline At +200 & \pm 1.3 & \pm 0.35 & \pm 0.16 \\
\hline At +300 & \pm 1.8 & \pm 0.55 & \pm 0.26 \\
\hline At +400 & \pm 2.3 & \pm 0.75 & \pm 0.36 \\
\hline
\end{tabular}

Resistivity sensors have a number of benefits if compared with other means of reading the temperature:

- stability of time and thermoelectrical specifications. They ensure accuracy and reliability of measurements, and they do not need to be calibrated very often;

- reproducibility of their linear thermoelectrical performance provides for the standardization of their calibration curve, which is the condition of interchangeability of RTDs;

- stability against external effects.

The sensors used in the course of the bench experiments are illustrated in Figs. 1, $a, b$. The data from sensors was transmitted and processed by a digital controller of temperature (Fig. 1, c). The sensors were calibrated before the experiments commenced.
The contact temperature was measured using the cutoff sensors method. The resistivity sensors of temperature were placed in the special holes bored in the mining rock slabs so that their contact elements faced the path of the diamond drill bit nose (Fig. 2).

In the course of drilling the drill bit cuts off the thermal sensor, the latter gets out of order. The temperature measured at the time of the sensor cutoff is considered to be the contact temperature.

In order to implement this approach, the pilot burnin of the tools and devices was carried out (on the pilot borehole); the position of the sensors mounting was defined with the reference to the pilot borehole. The distance between sensors was $30 \mathrm{~mm}$. Positioning of the sensors allowed measuring the temperature as the drill bit approached them; it was similar to measuring the temperature on various distances to the working nose of the drill bit. The sensors mounting holes were drilled using the hard alloy drills; the sensors were secured in the rock with concrete mortar.

In Fig. 3 you can see the mining rock slab mounted on the bench experiment table. In Fig. 3, $a$ you can see one used borehole (on the left side) and two pilot boreholes ready for drilling.

In Fig. 3, $b$ you can see the same mining rock slab after the experiments (the borehole on the right).

Illustration of the bench experiments stand based on the XY-1 boring rig which is used for core drilling of boreholes at the depth of up to $100 \mathrm{~m}$, is pictured in Fig. 4 .

Process water was used as drilling fluid. Mining rock is medium granular granite. A 59-mm diameter impregnated drill bit 01 И4 with 6 flushing channels was used for drilling (Fig. 5).

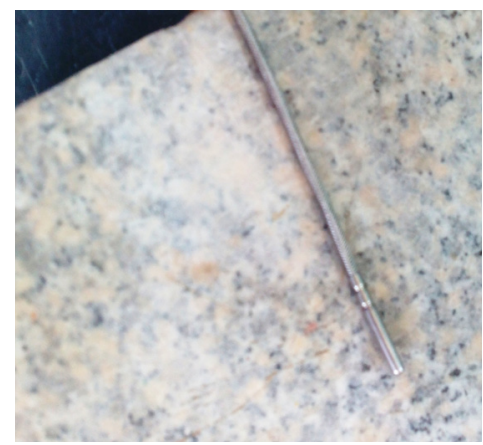

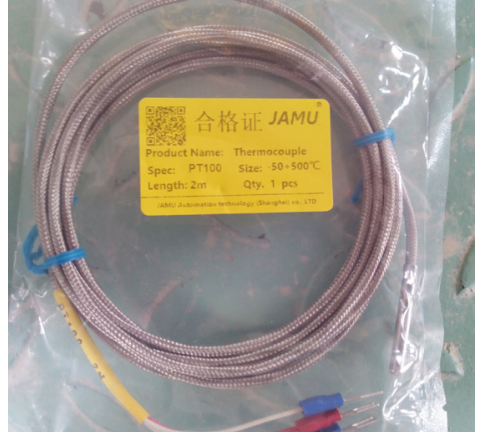

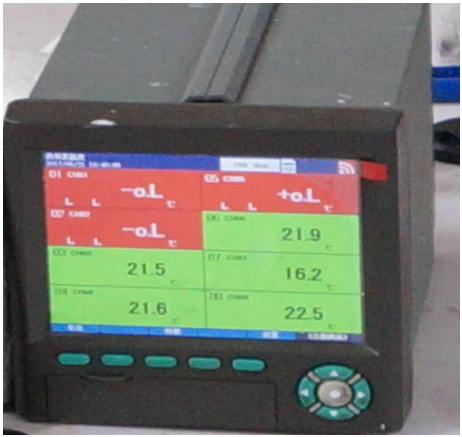

$c$

Fig. 1. Components of the measurement system used in the course of the experiments: sensor in the protection sleeve (a), illustration of the sensor (b), digital controller of temperatures (c)

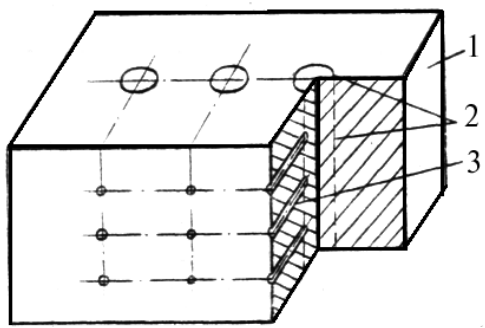

Fig. 2. Layout of sensors positioning in the mining rock: 1 - mining rock slab; 2 - projected profile of the borehole; 3 - sensors mounting holes

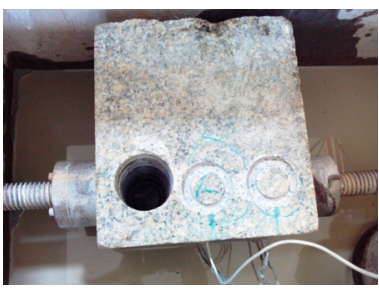

$a$

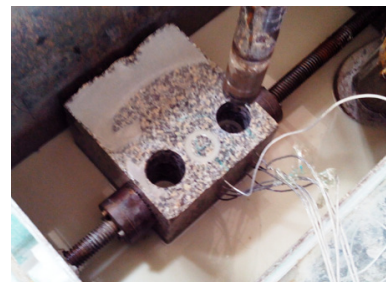

$b$
Fig. 3. Mining rock slab with mounted thermal sensors on the bench experiments table: $a$ - before drilling; $b$ - after drilling 


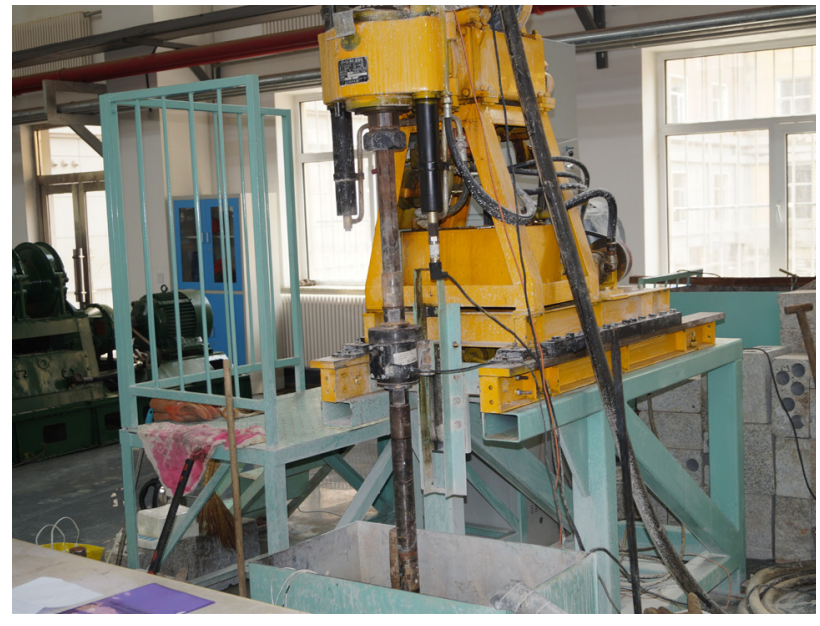

Fig. 4. Bench experiment stand

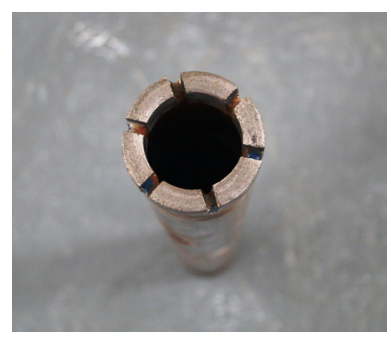

$a$

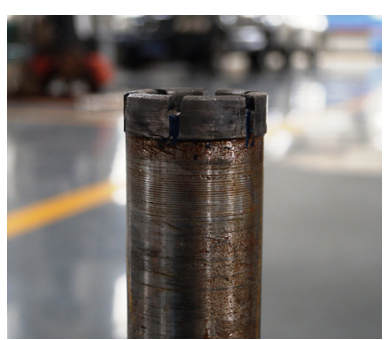

$b$
Fig. 5. Diamond drill bit used in the course of the experiments:

$a-$ top view; $b$ - side view

Constant axis load of $\mathrm{F}=8 \mathrm{kN}$ and rotation frequency $\mathrm{n}=400 \mathrm{rpm}$ were ensured in the course of the experiments. The said parameters were controlled using the control panel of the boring rig. Drilling fluid circulation rate was varying within the range from 9.2 to 39.0 liters per minute.

Drilling fluid supply mode maintained constant during each experiment. Upon passing of each control point by the drill bit (upon cutoff of the relevant sensor) the drilling process was stopped and adequate idle time was allowed to restore the initial conditions inside the borehole. After changing of the drilling fluid circulation rate, the drilling process continued again.

The outcomes of the experimental research in the form of the characteristic curve between the contact temperature and drilling fluid circulation rate are represented in Fig. 6.

As it is seen from the data provided in Fig. 6, the increasing of the contact temperature commences immediately upon decrease in the drilling fluid circulation rate below 25 liters per minute. At the rate below 10 liters per minute, the contact temperature rises to $370{ }^{\circ} \mathrm{C}$ and above. Therefore, by controlling the drilling fluid circulation rate, one can control the contact temperature in the downhole area. The obtained data can be used for verifying the estimation methods for the contact temperature determining.

Theoretical research. Mathematical modeling methods were applied to provide the theoretical evaluation of the action of drilling fluid circulation rate on the contact temperature. 1D mathematical model was developed to describe the process of drill bit heating; the said model is a system of one-dimensional equations of heat conductivity for various zones of the drill bit (diamonds, matrix and steel body of the drill bit). Applying this approach to the description of heat exchange process of the drill bit seems to be justified by the results of CFD-modeling defined in [11]. The research revealed that only the changes of the temperature field along the height of the drill bit are of significant nature. At that, when developing the calculation area along the height dimension of the drill bit, 4 specific zones were defined along which the geometrical characteristics and heat exchange ratios are assumed to be constant: the diamonds located on the bit nose $l_{1}$; the area of the drill bit matrix with end flushing channels $l_{2}$; the areas of the matrix with side flushing channels $l_{3}$ and the steel body of the bit $l_{4}$ (Fig. 7). The $x$ axis is oriented along the drill bit height, while the coordinate origin is located in the point of contact between the drill bit and mining rock.

The same physical assumptions as in work [11] were applied herein, so we can describe the mathematical mode as follows

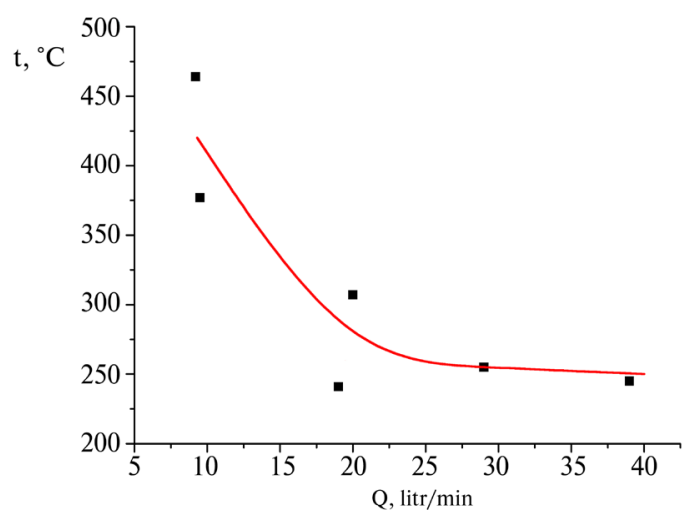

Fig. 6. The correlation of contact temperature $t$ and drilling fluid circulation rate $Q$ :

dotted graph - experimental data; curved line - averaged results based on the least-square deviation method

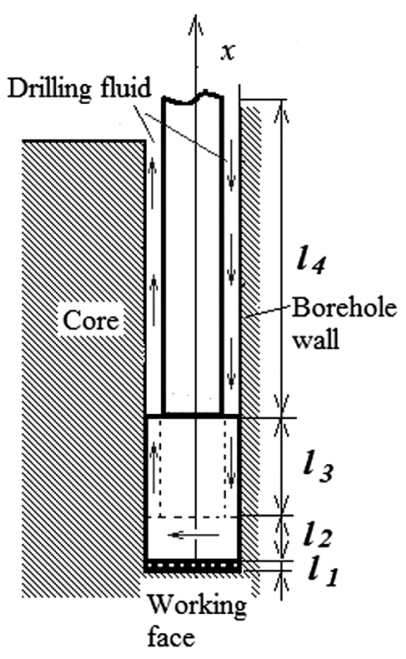

Fig. 7. Layout for developing of mathematical model: $l_{i}$-zones of bit; $x$ - coordinate axis 


$$
\begin{gathered}
c_{1} \rho_{1} \frac{\partial t_{1}}{\partial \tau}=\lambda_{1} \frac{\partial^{2} t_{1}}{\partial x_{1}^{2}} ; \\
c_{2} \rho_{2} \frac{\partial t_{2}}{\partial \tau}=\lambda_{2} \frac{\partial^{2} t_{2}}{\partial x_{j}^{2}}-A_{2} \cdot\left(t_{2}-t_{f}\right) ; \\
c_{3} \rho_{3} \frac{\partial t_{3}}{\partial \tau}=\lambda_{3} \frac{\partial^{2} t_{3}}{\partial x_{3}^{2}}-A_{3} \cdot\left(t_{3}-t_{f}\right) ; \\
c_{4} \rho_{4} \frac{\partial t_{4}}{\partial \tau}=\lambda_{4} \frac{\partial^{2} t_{4}}{\partial x_{4}^{2}}-A_{4} \cdot\left(t_{4}-t_{f}\right),
\end{gathered}
$$

where indices " $1,2,3,4$ " relate to the four areas alongside the drill bit height dimension; $\tau$ is the time; $\lambda$ is the heat conductivity of materials; $\rho$ is the density of materials; $c$ is the specific heat capacity of materials; $F$ is the cross section of the relevant area; $t_{f}$ is the temperature of drilling fluid.

Values $A_{j}$, describe the convection heat exchange between the drill bit and drilling fluid, and are defined as follows

$$
\begin{gathered}
A_{1}=0 ; \\
A_{2}=\frac{\alpha_{2} P_{2}}{F_{2}} ; \\
A_{3}=\frac{\alpha_{3} P_{3}}{F_{3}} ; \\
A_{4}=\frac{\alpha_{4} P_{4}+\alpha_{5} P_{5}}{F_{4}},
\end{gathered}
$$

where $\alpha_{2}$ is the heat transfer coefficient of end flushing channels; $\alpha_{3}$, is the heat transfer coefficient of side flushing channels; $\alpha_{4}, \alpha_{5}$ are the heat transfer coefficients of internal and external surfaces of drill bit steel body; $F_{j}$ are cross sections of each of the areas; $P_{2}$ is the aggregate perimeter of end flushing channels surface; $P_{3}$ is the aggregate perimeter of side flushing channels surface on the internal and external surfaces of the drill bit matrix; $P_{4}$, $P_{5}$ are the perimeters of internal and external side surfaces of the drill bit steel body.

Initial conditions for the system equations (1)

$$
\left.t_{j}\right|_{\tau=0}=t_{0}, j=1,2,3,4,
$$

where $t_{0}$ is the initial temperature of drill bit.

On the contact surface of bit diamonds and mining rock we determine the value of the heat flow generated by friction

$$
\left.\lambda_{1} F_{1} \frac{d t_{1}}{d x}\right|_{x=0}=-k_{\text {tool }} N
$$

where $k_{\text {tool }}$ is the drill bit heating ratio; $N$ is the power. Heating ratio depends on thermophysical properties of both mining rock and drilling tools. In general, the said ratio depends on the intensity of the convective heat exchange, and in simplistic terms it can be determined from the expression

$$
k_{\text {tool }}=\frac{1}{1+\frac{\lambda_{1}}{\lambda_{\text {rock }}} \sqrt{\frac{a_{\text {rock }}}{a_{1}}}},
$$

where $\lambda_{\text {rock }}, a_{\text {rock }}$ are the coefficients of heat transfer and temperature conductivity of the mining rock.

Power $N$ is defined by Shamshev's formula

$$
N=2 \cdot 10^{-4} P \cdot n \cdot D_{a v},
$$

where $P$ is the axial load of the drill bit, in daN; $n$ is the drill bit rotation frequency, rpm; $D_{a v}$ is the average diameter of drill bit, $\mathrm{m}$.

On the points of contact of the drill bit zones we determine the conditions of the thermal balance

$$
\begin{aligned}
& \left.t_{1}\right|_{x=l_{1}}=\left.t_{2}\right|_{x=l_{1}} ;\left.\quad \lambda_{1} F_{1} \frac{d t_{1}}{d x}\right|_{x=l_{1}}=\left.\lambda_{2} F_{2} \frac{d t_{2}}{d x}\right|_{x=l_{1}} ; \\
& \left.t_{2}\right|_{x=l_{2}}=\left.t_{3}\right|_{x=l_{2}} ;\left.\quad \lambda_{2} F_{2} \frac{d t_{2}}{d x}\right|_{x=l_{2}}=\left.\lambda_{3} F_{3} \frac{d t_{3}}{d x}\right|_{x=l_{2}} ; \\
& \left.t_{3}\right|_{x=l_{3}}=\left.t_{4}\right|_{x=l_{3}} ;\left.\quad \lambda_{3} F_{3} \frac{d t_{3}}{d x}\right|_{x=l_{3}}=\left.\lambda_{4} F_{4} \frac{d t_{4}}{d x}\right|_{x=l_{3}} .
\end{aligned}
$$

On the drill bit end we define the condition

$$
\left.\frac{d t_{4}}{d x}\right|_{x=L}=0,
$$

where $L=l_{1}+l_{2}+l_{3}+l_{4}$.

Action of drilling fluid circulation rate on thermal condition of the drill bit is defined through the heat exchange coefficients. A developed turbulent flow of the drilling fluid is seen in the areas of the drill bit casing and side flushing channels, the heat exchange coefficients were defined by the formula [18]

$$
\alpha_{j}=0.021 \cdot \operatorname{Re}_{j}^{0.8} \cdot \operatorname{Pr}^{0.43} \cdot \frac{\lambda_{f}}{D_{j}}, \quad j=3,4,
$$

where $R e_{j}=\frac{Q D_{j}}{k v_{f} S_{j}}$ Reynolds number; $Q$ is the drilling fluid volumetric flow rate; $k$ is the number of flushing channels; $S$ cross section of flushing channel; $D_{j}$ is the hydraulic diameter; $\operatorname{Pr}=\frac{v_{f}}{a_{f}}$ is Prandtl number; $\lambda_{f}, v_{f}, a_{f}$ are the coefficients of heat exchange, cinematic viscosity and thermal conductivity of drilling fluid, respectively.

Model (1) was designed for single-layer diamond drill bits. This model can be easily modified for impregnated drill bits by way of determining $l_{1}=0$, and exclusions the first equation from system (1). Boundary condition (3) is not considered herein, while condition (4) is defined as

$$
\left.\lambda_{2} F_{2} \frac{d t_{2}}{d x}\right|_{x=0}=-k_{\text {tool }} N
$$


where $\lambda_{2}$ is the heat exchange coefficient of the composite material of the drill bit and impregnated drilling diamonds. The said coefficient is also used to determine the drill bit heating index.

According to computer modeling data [10], the flow of drilling fluid turns around in the end flushing channels, and some dead water zones are formed in the close vicinity to the drill bit surface, which results in decreasing of the heat conductivity rate. It is reasonable, therefore, to assume that a laminar boundary layer and developed heat exchange processes occur in the near-wall regions of the end flushing channels. At that, the heat exchange coefficient is defined by ratio [18]

$$
\alpha_{2}=3.65 \frac{\lambda_{f}}{D_{2}},
$$

where $D_{2}$ is the hydraulic diameter of end flushing channels.

The numerical solution of task $(1-7)$ for the conditions of the above mentioned experiment was performed hereunder. Table 2 contains the comparative analysis of both experimental and calculated data. The temperature values $T_{\exp }$ are found to be in conformity with the results obtained by experimental research, while $T_{\text {calc }}$ are in conformity with the outcomes of calculations based on the proposed model at the same initial conditions as in the experiment. The difference $\Delta$ was calculated in absolute values and in percent by formula

$$
\Delta=\frac{\left|T_{\exp }-T_{c a l c}\right|}{T_{\exp }} 100 \% .
$$

In is evident from Table 2 that the modeling results are in satisfactory conformity with the experimental data. The difference between the experimental and calculated values is ranging within 3-22\%, the average difference is $10.2 \%$, which can be considered satisfactory enough.

Summary. The following conclusions can be made upon the results of the performed work:

- the results of the bench experimental research of the influence of drilling fluid flow rate on the contact temperature have confirmed the possibility to control the thermal factor in the downhole area and thermal stimulation of the mining rock by way of changing the drilling fluid flow rate;

- the outcomes of the comparative analysis of bench experimental and calculated data have confirmed the possibility to use the described mathematical model to evaluate the influence of drilling fluid flow rate on the contact temperature.

Table 2

\begin{tabular}{|c|c|c|c|c|c|}
\hline $\begin{array}{c}\text { Item } \\
\text { № }\end{array}$ & $\begin{array}{c}\text { Drilling fluid flow rate } \\
\text { Q, } \\
1 / \mathrm{min}\end{array}$ & $\begin{array}{l}\text { Experimental value of } \\
\text { contact temperature } \mathrm{T}_{\text {exp }}, \\
{ }^{\circ} \mathrm{C}\end{array}$ & $\begin{array}{c}\text { Calculated value of } \\
\text { contact temperature } \mathrm{T}_{\text {calc }}, \\
{ }^{\circ} \mathrm{C}\end{array}$ & \multicolumn{2}{|c|}{$\begin{array}{c}\text { Difference between } \\
\text { the experimental and } \\
\text { calculated values, } \Delta, \\
\left({ }^{\circ} \mathrm{C} / \%\right)\end{array}$} \\
\hline 1 & 9.2 & 464 & 356 & 108 & 22 \\
\hline 2 & 9.5 & 377 & 356 & 21 & 6 \\
\hline 3 & 19.0 & 241 & 270 & -29 & 12 \\
\hline 4 & 20.0 & 307 & 270 & 37 & 12 \\
\hline 5 & 29.0 & 255 & 248 & 7 & 3 \\
\hline 6 & 39.0 & 245 & 239 & 6 & 3 \\
\hline
\end{tabular}

Comparative analysis of experimental and calculated data

\section{References.}

1. Bondarenko, V., Svietkina, O. and Sai, K., 2017. Study of the formation mechanism of gas hydrates of methane in the presence of surface-active substances. Eastern-European Journal of Enterprise Technologies, 5-6(89), pp. 4855. DOI: 10.15587/1729-4061.2017.112313.

2. Zhang, W., Sun, Q., Hao, S., Geng, J. and Lv, C., 2016. Experimental study on the variation of physical and mechanical properties of rock after high temperature treatment. Applied Thermal Engineering, 98, pp. 1297-1304. 3. Khomenko, O. Ye. and Maltsev, D. V., 2013. Laboratory research of influence of face area dimensions on the state of uranium ore layers being broken. Naukovyi Visnyk Natsionalnoho Hirnychoho Universytetu, 2, pp. 31-37.
4. Khomenko, O. Ye., 2012. Implementation of energy method in study of zonal disintegration of rocks. Naukovyi Visnyk Natsionalnoho Hirnychoho Universytetu, 4, pp. 44-54.

5. Hillson, S.D. and Tester, J.W. 2015. Heat Transfer Properties and Dissolution Behavior of Barre Granite as Applied to Hydrothermal Jet Drilling with Chemical Enhancement Sean. Proceedings, Fortieth Workshop on Geothermal Reservoir Engineering Stanford University, Stanford, California, January, pp. 26-28, SGP-TR-2041.

6. Kant, M.A., Rossi, E., Madonna, C., Höser, D. and P. Rudolf von Rohr, 2017. A theory on thermal spalling of rocks with a focus on thermal spallation drilling, 
J. Geophys. Res. Solid Earth, 122, pp. 1805-1815. DOI: 10.1002/2016JB013800.

7. Kocis, I., Kristofic, T., Gajdos, M., Horvath, G. and Jankovic, S., 2015. Utilization of electrical plasma for hard rock drilling and casing milling. In: SPE/IADC Drilling Conference and Exhibition. Society of Petroleum Engineers. DOI: 10.2118/173016-MS.

8. Dreus, A. Yu., Sudakov, A. K., Kozhevnykov, A. A. and Vakhalin, Yu. N., 2016. Study of thermal strength reduction of rock formation in the diamond core drilling process using pulse flushing mode. Naukovyi Visnyk Natsionalnoho Hirnychoho Universytetu, 3, pp. 5-10.

9. Kryshtopa, S., Petryna, D., Bogatchuk, I., Prunko, I. and Melnyk, V., 2017. Surface Hardening of 40KH Steel by Electric-Spark Alloying. Materials Science, 53(3), pp. 351-358.

10. Pivnyak, G., Bondarenko, V., Kovalevs'ka I., and Illiashov, M., 2013. Mining of Mineral Deposits. London: CRC Press, Taylor \& Francis Group. DOI: 10.1201/b16354. 11. Dreus, A., Kozhevnikov, A., Lysenko, K. and Sudakov, A., 2016. Investigation of heating of the drilling bits and definition of the energy efficient drilling modes. Eastern-European Journal of Enterprise Technologies, 3(7(81)), pp. 41-46.

12. Juraev, R. U. and Merkulov, M.V., 2016. Experimental study of heat power of the downhole at drilling a well using air. Mining information analytical bulletin, 1, pp. 288-293. 13. Li, J., Guo, B., Yang, S. and Liu, G., 2014. The complexity of thermal effect on rock failure in gas-drilling shale-gas wells. Journal of Natural Gas Science and Engineering, 21, pp. 255-259.

14. Gorman, J. M., Abraham, J. P. and Sparrow, E. M., 2014. A novel, comprehensive numerical simulation for predicting temperatures within boreholes and the adjoining rock bed. Geothermics, 50, pp. 213-219.

15. Kryshtopa, S., Kryshtopa, L., Bogatchuk, I., Prunko, I. and Melnyk, V., 2017. Examining the effect of triboelectric phenomena on wear-friction properties of metal-polymeric frictional couples. Eastern European Journal of Enterprise Technologies, 1(5), pp. 40-45.

16. Yevtushenko, A.A., Kuciej, M. and Yevtushenko, O., 2015. Modelling of the frictional heating in brake system with thermal resistance on a contact surface and convective cooling on a free surface of a pad. International Journal of Heat and Mass Transfer, 81, pp. 915-923.

17. Dreus, A., Lysenko, K., Kozhevnykov, A. and Liu, B., 2017. Modeling hydrodynamics of the flushing fluid intermittent flow in the hydraulic system of the diamond bit. Mining of Mineral Deposits, 11(2), pp. 84-90. DOI: 10.15407/mining11.02.084.

18. Sunden, B., 2012. Introduction to heat transfer. Southhampton: WITpress.

Мета. Встановити вплив витрати промивальної рідини на контактну температуру під час обертового алмазного буріння імпрегнованою коронкою, верифікація математичної моделі процесу нагрівання алмазної коронки під час буріння свердловин.

Методика. Стендові експериментальні дослідження й теоретичний аналіз із використанням методів математичного моделювання.
Результати. У результаті стендових експериментів отримані дані щодо впливу витрати промивальної рідини на контактну температуру при бурінні імпрегнованою алмазною буровою коронкою діаметром 59 мм. Представлена математична модель нагрівання бурової коронки при бурінні зі змінною витратою промивальної рідини, що грунтується на системі диференціальних рівнянь теплопередачі. Проведено порівняльний аналіз експериментальних і розрахункових даних, результати якого підтверджують достовірність математичного моделювання процесів теплопередачі у свердловині при бурінні.

Наукова новизна. Запропонована методика експериментального дослідження контактної температури під час стендового експерименту з буріння свердловини з використанням датчиків опору. Отримані нові експериментальні дані, що дозволили встановити закономірність зміни контактної температури від зміни подачі промивальної рідини до вибою. Доведена адекватність запропонованої математичної моделі, що дозволяє прогнозувати температурний режим на вибої свердловини під час буріння. Результати роботи дозволяють обгрунтувати ефект підвищення продуктивності алмазного буріння при переході від постійних параметрів роботи до змінних у часі.

Практична значимість. Встановлені закономірності впливу витрати промивальної рідини на контактну температуру системи ,інструмент - вибій“ під час буріння свердловини. Виконані дослідження підтвердили можливість управління тепловим режимом буріння за рахунок зміни витрати промивальної рідини. Таким чином, підвищення продуктивності алмазного буріння можливе завдяки збільшенню термічного впливу на гірську породу. Розроблена математична модель дозволяє прогнозувати контактну температуру під час буріння свердловини для різних значень витрат промивальної рідини. Використання цієї моделі дає змогу визначити припустиме зменшення витрати промивальної рідини для запобігання аномальному теплофізичному зношенню коронки.

Ключові слова: буріння, тепловий режим, математична модель, нагрівання коронок

Цель. Определение влияния расхода промывочной жидкости на контактную температуру при вращательном алмазном бурении импрегнированной коронкой, верификация математической модели процесса нагрева коронки при бурении.

Методика. Стендовые экспериментальные исследования, теоретический анализ с использованием методов математического моделирования.

Результаты. В результате стендовых исследований получены экспериментальные данные по влиянию расхода промывочной жидкости на контактную температуру при бурении импрегнированной коронкой диаметром 59 мм по граниту. Представлена математическая модель нагрева буровой коронки при изменяющемся расходе промывочной жидкости, которая основана на системе дифференциальных уравнений теплопереноса. Выполнен сравнительный анализ экспериментальных и расчетных данных, резуль- 
таты которого подтверждают достоверность математического моделирования процесса теплообмена на забое при бурении скважин.

Научная новизна. Предложена методика экспериментального измерения контактной температуры при стендовом бурении скважин с использованием датчиков сопротивления. Получены новые экспериментальные данные, позволившие установить закономерность изменения контактной температуры от изменения подачи промывочной жидкости на забой. Доказана адекватность предлагаемой математической модели, которая позволяет прогнозировать температурный режим на забое при бурении скважины. Результаты работы позволяют обосновать эффект повышения производительности алмазного бурения при переходе от постоянных во времени режимных параметров к переменным.

Практическая значимость. Установлены закономерности влияния расхода промывочной жидкости на контактную температуру системы „инструмент - забой“ при бурении скважин. Выполненные исследования подтвердили возможность управления температурным режимом бурения за счет изменения расхода промывочной жидкости. Таким образом, повышение производительности алмазного бурения возможно за счет увеличения теплового воздействия на горную породу. Разработанная математическая модель позволяет прогнозировать контактную температуру при бурении для различных значений расхода промывочной жидкости. Использование данной модели дает возможность определить допустимое снижение расхода промывочной жидкости для предотвращения аномального теплофизического износа буровой коронки.

Ключевые слова: бурение, температурный режим, математическая модель, нагрев буровых коронок

Рекомендовано до публікації докт. техн. наук О.М. Давиденком. Дата надходження рукопису 02.12.16. 